\title{
Analisis Komunikasi Organisasi Partai Politik Islam
}

\author{
Dedi Sahputra \\ Dosen Sekolah Tinggi Ilmu Komunikasi “Pembangunan” Medan
}

\begin{abstract}
Abstrak
Kinerja sebuah organisasi dilihat dari efisiensi para anggotanya dalam kinerjanya masing-masing. Sedangkan kinerja para anggota organisasi dipengaruhi oleh faktor internal dan faktor eksternal. Sedangkan faktor utama dari efektivitas kinerja organisasi dilihat dari pelayanannya dalam interaksinya dengan lingkungan sekitarnya. Karena organisasi yang semakin dapat memberikan pelayanan yang terbaik maka ia akan semakin mendapat penerimaan lingkungannya. Analisis komunikasi organisasi R. Wayne Pace digunakan dalam menganalisis partai politik Islam. Di mana ajaran Islam sebagai landasan utama partai politik Islam telah meliputi berbagai aplikasi dari sistem nilai yang dianut dalam organisasi modern yang berasal dari dunia Barat.
\end{abstract}

Kata Kunci : Efektivitas Organisasi, Kinerja

\section{A. Pendahuluan}

Partai politik Islam yang memiliki sejarah panjang dalam politik di Indonesia merupakan suatu kajian yang dapat dilihat melalui pendekatan komunikasi. Komunikasi organisasi adalah pengiriman dan penerimaan berbagai pesan organisasi di dalam kelompok formal maupun informal dari suatu organisasi ( Romli, 2011:2 )

Sedangkan dalam hal ini partai politik Islam dilihat sebagai organisasi yang memiliki organ-organ di dalamnya yang bekerja satu sama lain. Islam politik di Indonesia sebenarnya sudah lama muncul, jauh sebelum Masyumi didirikan. Hal ini disebabkan Islam telah menjadi bagian dan pelopor bagi masyarakat pribumi dalam memperjuangkan dan menegakkan identitas ( Warjio, $2018: 37-38$ )

Komunikasi, meski tidak menjamin terjalinnya efisiensi operasional organisasi, tetapi komunikasi yang tidak efisien akan menimbullkan suatu kondisi yang akan menghalangi terjadinya efisiensi organisasi. Komunikasi dan fungsi sumber daya manusia adalah hal yang saling terkait satu sama lain. Komunikasi telah lama dipahami sebagai suatu hal yang sangat 
berarti bagi kelangsungan hidup baik orangnya maupun organisasinya. Masalah akut dalam komunikasi pada pertengahan abad ke sembilanbelas dan dalam beberapa jurnal ilmu popular baru telah menemukan bahwa untuk meyakinkan publik, ilmu komunikasi adalah suatu tuntutan yang penting ( Russell, 2010:8 ). Selanjutnya perkembangan ilmu komunikasi menjadi suatu fenomena dan menjadikan ilmu ini sebagai bagian dari ilmu pengetahuan temporer.

Termasuk di dalamnya adalah komunikasi organisasi. Sistem informasi organisasi mempengaruhi cara organisasi dalam upaya mengatasi masalahnya. Karena organisasi terdiri dari kumpulan orang-orang maka masalah-masalah proses informasi individu menjadi bagian dari masalah yang lebih besar bagi organisasi. Ini berarti bahwa individu-individu di dalam organisasi adalah orang-orang yang bisa menjadi bagian dari solusi dari permasalahan yang dihadapi organisasi, tetapi sebaliknya, individu-individu tersebut bisa juga menjadi bagian dari masalah di dalam organisasi. Tidak jarang bahkan permasalahan yang muncul di dalam organisasi adalah disebabkan oleh interaksi di dalam organisasi, dan itu disebabkan oleh komunikasi yang tidak efisien di antara individunya.

Apa yang terjadi pada masalah komunikasi di dalam organisasi inilah yang disebut disebut dengan krisis komunikasi. Untuk itu perlu ada rencana krisis komunikasi, untuk melakukan langkah-langkah strategis. Rencana krisis komunikasi adalah alat penting dalam berurusan dengan krisis, bencana atau kecelakaan. Setiap perusahaan, tak peduli di sektor apa, jenis aktivitas apa ataupun seberapa besar ukurannya harus memiliki up-to-date rencana krisis komunikasi ( Anthonissen, $2008: 15$ )

Apa yang diharapkan dari komunikasi organisasi yang efektif antara lain adalah keberlanjutan perkembangan organisasi. Keberlanjutan perkembangan adalah peningkatan perhatian dan publisitas, tidak hanya oleh pemerintah tetapi juga dalam sektor privat, khususnya perusahaan multinasional. Pertanyaan model neo-klasikal dan pada fokus dalam basis komunikasi berkelanjutan dasar bagi pesan yang disampaikan yang dalam hal ini adalah hasil dari penilaian berkelanjutan ( Jonas, $2010: 100$ )

Selanjutnya analisis adalah proses mempelajari sifat sesuatu hal, menentukan elemenelemen konstituennya, atau menentukan fitur-fitur penting dan hubungan di antaranya. Sebuah analisis sumber daya manusia yang berkembang adalah orang yang mempelajari status komunikasi dan aktivitas lainnya dari para anggota sebuah organisasi. Analisis digunakan secara ekstensif dalam organisasi untuk menentukan status saat ini dari fungsi, program, dan berbagai aktivitas. Analisis biasanya mencari tahu apa yang terjadi dan untuk memutuskan mana yang digunakan pada waktu tertentu. Seperti halnya diagnosa medis atau 
diagnosis otomotif, diagnosis organisasi memberikan gambaran bagaimana berbagai organ dalam berfungsi. Dari pengenalan tentang analisis ini, memungkinkan untuk mengenal tentang kekuatan-kekuatan dan kelemahan-kelemahan serta menetapkan prosedur-prosedur untuk melakukan opsi perbaikan.

Analisis didasarkan dalam filosofi penyelesaian masalah. Sebelum sebuah keputusan diambil, sebuah masalah harus telah dikenali. Sebuah masalah didefinsikan sebagai perbedaan antara apa yang terjadi dengan apa yang seharusnya terjadi. Sifat dan lokasi atas perbedaan antara apa yang terjadi dengan apa yang diinginkan untuk terjadi, biasanya ditentukan oleh upaya untuk membuat perbedaan. Selanjutnya dalam tulisan ini menggunakan analisis komunikasi organisasi R.Wayne Pace yang dielaborasikan dengan partai politik Islam.

\section{B. Partai Politik Islam}

Menurut pakar-pakar, politik adalah serangkaian proses yang dilakukan baik oleh individu dengan penekanan pada pemerintahan dan di dalamnya tertumpu pada proses kebijakan publik untuk mencapai tujuan. Pemahaman tersebut memiliki benang merah di mana kekuasaan dan upaya mencapai tujuan menjadi hal yang utama ( warjio. 2016:88 )

Partai politik Islam di Indonesia dalam sejarahnya telah mewarnai sejak berdirinya negara ini. Determinasi nilai agama dalam dinamika politik merupakan suatu keniscayaan yang memang semestinya terjadi. Agama sejauh ini telah mapan sebagai salah satu variabel penting yang turut menentukan warga sebuah pentas politik ( Sahputra, 2016:3 )

Agama sebagai sebuah sistem bagi sub sistem politik harus memiliki syarat bagi kelanggengannya dari masa ke masa. Agama Islam menurut George Bernand Shaw adalah satu-satunya agama yang memiliki kepastian untuk berasimilasi tterhadap perubahan tahap eksistensi manusia, yang membuatnya tetap memiliki daya tarik yang kuat dalam setiap abad. Agama ini adalah agama masa depan ( Harahap, 2015 : xv )

Umumnya dalam pemikiran politik Islam, pandangan tentang masalah hubungan agama dan negara masih berpusat pada tiga paradigma. Pertama, paradigma yang menyatakan bahwa antara agama dan negara merupakan kesatuan yang tidak terpisahkan (integrated). Kedua, paradigma yang menyatakan antara agama dan negara merupakan satu kesatuan yang saling terkait dan berhubungan (simbiotik). Ketiga, paradigma yang menyatakan antara agama dan negara merupakan suatu yang harus terpisah (sekuler). 
Namun kekuatan politik partai politik Islam yang cenderung melemah berdampak dengan tidak terimplementasikannya ajaran-ajaran Islam dalam kehidupan berbangsa dan bernegara.

Kelemahan partai politik Islam seperti Partai Keadilan Sejahtera (PKS) di Sumatera Utara adalah pada pemahamannya para elitnya terhadap prinsip-prinsip komunikasi Islam yang tidak utuh, manakala elit Partai Persatuan Pembangunan (PPP) Sumatera Utara tidak memahami prinsip-prinsip komunikasi Islam secara baik dan benar. Dalam bidang strategi, PKS mulai menanggalkan simbol-simbol Islam, namun pada saat yang sama belum menyentuh substansi ajaran Islam secara menyeluruh. Sedangkan PPP Sumatera Utara lebih menekankan pada simbol, namun secara substansial justru meninggalkan ajaran Islam. Partai politik Islam cenderung mengikuti tujuan electoral berbanding mengimplementasikan ajaran Islam dalam organisasi partai politiknya.

PKS merupakan salah satu partai politik dakwah yang awalnya dikenal dengan nama Partai Keadilan (PK). PK didirikan iklim demokrasi Indonesia yang peluangnya dibuka oleh gerakan reformasi 1998 setelah jatuhnya Presiden Soeharto ( Warjio, 2016:42)

Dari gerakan dakwah di kampus menjadi partai politik di pentas nasional juga memiliki konsekuensi. Pilihan menjadi partai bukan tanpa risiko. PKS adalah partai yang ditopang basis kader yang militan, muda, terdidik, penduduk kota, tapi punya pandangan Islam konservatif. Pilihan menjadi partai politik kadang memaksa PKS untuk bermain dalam dunia abu-abu yang penuh kompromi, negosiasi dan godaan kekuasaan.

Kondisi partai politik Islam sebagaimana yang direpresentasikan oleh PKS dan PPP sebagaimana diuraikan di atas menunjukkan bahwa secara organisasi partai politik Islam belum menunjukkan kondisi yang ideal dalam arti mewakili kepentingan umat Islam sesuai dengan ajaran dalam agama Islam. Partai politik Islam juga belum mendapatkan suara signifikan meski Indonesia adalah negara dengan pemeluk Islam terbesar di dunia. Jika membandingkan hasil Pemilu pertama (1955) dengan hasil Pemilu 2009 menunjukkan ketidaksinkronan antara jumlah umat Islam yang mayoritas di Indonesia dengan jumlah pemilih partai Islam ( Muhtadi, $2012: 220$ )

\section{Analisis Komunikasi Organisasi Partai Politik Islam}

Suatu masalah organisasi, tak terkecuali organisasi partai politik Islam adalah perbedaan antara dengan apa yang kita pikirkan untuk mengambil peran dalam komunikasi dan peran yang akan kita inginkan. Dengan demikian untuk menentukan apakah sesuatu harus diubah adalah dengan membandingkan apa yang tengah dilakukan sekarang dengan 
ukuran-ukuran organisasi yang efektif. Contohnya seperti penurunan jumlah pemilih, absensi, ketidapedulian, rendahnya pencapaian tujuan, keluhan-keluhan, kesalahan kerja, kecelakaan dan berbagai konsekuensi kerja dalam organisasi yang berbeda dengan apa yang diinginkan. Pertanyaannya adalah "Apa yang terjadi di dalam organisasi ketika hasil-hasil dalam konsekuensinya berbeda dengan apa yang diinginkan?" Dengan kata lain, pengamatan dari konsekuensi-konsekuensi mungkin merupakan respons dari tidak memadainya atau tidak sehatnya sistem komunikasi dan sebagai indikasi kelemahan sumber daya manusianya.

Analisis memberi gambaran dasar untuk memilih, mendesain dan mengimplementasikan strategi-strategi untuk membawa perubahan dalam dan perkembangan orang-orang serta organisasinya. Melalui proses analisis, kesulitan-kesulitan dapat dikenali dan diklasifikasikan untuk melakukan proses perbaikan. Analisis dapat menyediakan informasi dalam isu penting yang berhubungan dengan pengembangan sumber daya manusia: kinerja karyawan dalam tugasnya, dan kurangnya kemampuan. Analisis sering dapat melampaui pengenalan atas kekurangan kinerja individu dan mengungkapkan hal yang sangat berarti tentang organisasi itu sendiri. Menejerial organisasi, filosofi operasional, dan asumsiasumsi, kepemimpinan, pengambilan keputusan dan sistem penghargaan, komunikasi interpersonal, pengarus organisasi, grup dinamis, konflik, arus informasi, dan elemen lainnya dari komunikasi organisasi dapat dipahami melalui analisis.

\section{Proses Analisis}

\begin{tabular}{|c|c|c|c|c|}
\hline $\begin{array}{l}\text { Historical } \\
\text { Perfomance }\end{array}$ & $\begin{array}{l}\text { Current } \\
\text { Perfomance }\end{array}$ & $\begin{array}{l}\text { Future } \\
\text { Perfomance }\end{array}$ & $\begin{array}{l}\text { Problem } \\
\text { Perfomance }\end{array}$ & $\begin{array}{l}\text { Problem } \\
\text { Clasification }\end{array}$ \\
\hline $\begin{array}{l}\text { What has happened } \\
\text { In the past }\end{array}$ & $\begin{array}{l}\text { What is happening } \\
\text { now? }\end{array}$ & $\begin{array}{l}\text { What ought to be } \\
\text { Happening tomorrow? }\end{array}$ & $\begin{array}{l}\text { Are there differences } \\
\text { between what is happening } \\
\text { and what ought to be } \\
\text { happening? } \\
\text { Are the differences important } \\
\text { enough to do something } \\
\text { about? }\end{array}$ & $\begin{array}{l}\text { Are the } \\
\text { perfomance } \\
\text { deficiencies } \\
\text { training needs } \\
\text { or are they } \\
\text { development } \\
\text { needs? }\end{array}$ \\
\hline $\begin{array}{l}\text { Point of } \\
\text { Concern }\end{array}$ & $\begin{array}{l}\text { Documentation } \\
\text { of Concern }\end{array}$ & $\begin{array}{l}\text { Development } \\
\text { of Guidelines }\end{array}$ & $\begin{array}{l}\text { Point of } \\
\text { Comparison }\end{array}$ & $\begin{array}{l}\text { Point of } \\
\text { Determination }\end{array}$ \\
\hline
\end{tabular}

Historical Performance: Point of Concern - Semua organisasi memiliki tipe sejarahnya sendiri. Biasanya sangat sulit bagi pendatang baru untuk memahami sebuah organisasi sebagai apa yang dilakukannya berdasarkan masa lalu. Analisis biasanya didasari oleh adanya perasaan tentang sesuatu yang salah. Jika sesuatu yang terjadi di masa lalu 
memiliki analisis yang positif maka tidak mungkin dilakukan analisis yang banyak, meski analisis yang sederhana dan informal.

Current Perfomance: documentation of Concern - Ketika keprihatinan telah dirasakan, langkah selanjutnya adalah menyediakan beberapa dokumentasi untuk perhatian yang sering menjadi kritik paling efektif bagi peneliti dan konsultan. Namun, pengembangan sumber daya manusia dan departemen pengembangan organisasi menemukan bahwa keprihatinan-keprihatinan tersebut mesti didokumentasikan jika akan dipercaya dan diterima sebagai dasar bagi program pelatihan-pelatihan dan pengembangan-pengembangan.

Future Performance: Development of Guidelines - Tingkat ketiga dalam analisis adalah melibatkan penemuan atau pengembangan pedoman untuk memutuskan seperti apa kinerja, perilaku, aktivitas, kemampuan, pengetahuan, atau perubahan organisasi diharapkan. Ini semua memerlukan seperangkat panduan untuk membantu dalam memikirkan tentang kinerja ke depan. Panduan dapat difokuskan dalam tiga bagian: (1) deskripsi pekerjaan dan posisi, (2) pernyataan standar kinerja, (3) kebijakan-kebijakan.

Problem Identification: Point of Comparison - Tingkat keempat dalam analisis termasuk mengenali masalah-masalah. Dalam terminologi yang paling sederhana, proses analisis masalah terdiri dari menentukan perbedaan antara apa yang Anda miliki dengan apa yang ingin Anda miliki. Inti dari perbandingan berupaya untuk menjawab pertanyaan, “Apakah perbedaan cukup penting untuk melakukan sesuatu?" Jika dokumentasi masalah yang menjadi perhatian dan panduan sudah jelas, perbedaan-perbedaan mungkin akan mudah untuk dikenali.

Problem Classification: Point of Determination - Kelima yang merupakan tingkat final dalam analisis adalah masalah penentuan. Pertanyaan untuk dijawab ada di sini, “Apakah kinerja yang tidak efisien perlu pelatihan atau memerlukan pengembangan?" Perlu didefinisikan dengan kebutuhan, sebuah kekurangan akan sesuatu yang dibutuhkan oleh keadaan. Dalam pengembangan sumber daya manusia dan komunikasi organisasi, sebuah analisis kebutuhan terdiri dari suatu upaya untuk mendokumentasikan apakah perasaan para karyawan dalam sebuah organisasi merasa kurang atau dibutuhkan untuk menunjukkan efisiensi kerja mereka. Penekanan dalam analisis kebutuhan adalah apakah karyawan memersepsikan sebagai suatu kekurangan, keinginan atau suatu kondisi yang memerlukan perubahan ( R. Wayne Pace ) 


\section{Pendekatan Untuk Mendokumentasikan Kebutuhan Dan Ketidakefisienan}

"Analisis tugas adalah sebuah metode untuk menentukan persyaratan kinerja spesifik untuk suatu pekerjaan dalam rangka mengenali apakah anggota organisasi harus mengetahui dan menyelesaikan pekerjaannya. Dalam hal ini yang menjadi penting adalah ketrampilan spesifik untuk menunjukkan kinerja spesifik pula. Ketrampilan teknik adalah kemampuan menunjukkan atau menyelesaikan tugas khusus dengan baik. Seperti kemampuan yang berasal dari pengetahuan atau kepakaran yang diperoleh dari pendidikan ataupun dari pengalaman. Sedangkan pusat dari pekerjaan manajerial dan kepemimpian tim adalah keterampilan manusia, atau kemampuan untuk bekerja dengan baik bersama orang lain. Mereka memunculkan semangat kepercayaan, antusiasme dan keterlibatan inti dalam hubungan antarpersonal. Orang dengan ketrampilan kemanusiaan yang baik akan memiliki kualitas yang tinggi atas kesadaran pribadi dan kapasitas untuk memahami atau berempati dengan perasaan orang lain." (Osborn, 2002:11-12)

Analisis tugas adalah metode untuk menentukan secara tepat detil dan secara terukur kebutuhan kinerja manusia untuk meningkatkan tujuan manajemen secara spesifik, perlengkapan dan kondisi yang diperlukan untuk melakukan pekerjaan, dan persyaratan ketrampilan dan pengetahuan untuk karyawan. Analisis tugas termasuk di dalam sepuluh langkah:

1. Membuat sebuah daftar untuk semua tugas dan sub tugas yang diperlukan untuk melakukan pekerjaan. Idenya adalah untuk mengenali apakah yang harus dilakukan dan apakah langkah-langkah untuk melakukan pekerjaan.

2. Rekam kapan dan sesering apa setiap tugas dikerjakan. Frekuensi dengan tugas-tugas terselesaikan harus dicatat. Jika tugas diselesaikan setiap Selasa, kemungkinan diperlakukan berbeda dengan yang lain yang diselesaikan hanya setiap enam bulan. Jenis-jenis masalah mungkin berkembang dan perbedaan di permukaannya bisa berarti perbedaan pendekatan untuk membuat perbedaan, rancangan sesi pelatihan, dan memperkuat pelajaran.

3. Tingkat penerimaan kinerja terkait dengan setiap tugas utama. Jika mungkin, sesuatu yang spesifik dapat terukur dilihat dari kinerja penerimaan, harus dicatat. Standar terbaik mengacu pada ukuran seperti waktu, jarak, dan angka kesalahan.

4. Catat yang dianggap penting dari setiap tugas untuk mencapai keseluruhan tujuan pekerjaan.

5. Buat daftar persyaratan kemampuan dan pengetahuan untuk melakukan tugas. Di tahap ini dalam analisis tugas, kita menaruh perhatian pada apa yang perlu anggota organisasi ketahui dan kemampuan apa yang perlu dimiliki karyawan untuk menyelesaikan tugasnya. 
6. Catat jenis aktivitas belajar yang ada. Beberapa tugas memerlukan bagi anggota organisasi untuk memberitahukan perbedaan antara dua atau lebih hal, sedangkan yang lain memerlukan mengingat nama-nama ataupun peralatan-peralatan, ketiga mungkin memerlukan penentuan apakah sesuatu sudah benar, dan keempat mungkin memerlukan gerakan fisik, sedangkan kelima mungkin khusus memerlukan ceramah.

7. Rekam kondisi di mana tugas dilakukan. Beberapa tugas harus dilakukan di bawah banyak sekali tekanan orang yang menyaksikan sedangkan yang lain relatif sepi tanpa perhatian di mana koreksi dapat dilakukan sendiri. Beberapa tugas dilakukan dengan orang lain sedangkan yang lainnya dilakukan sendirian.

8. Buat perkiraan seberapa sulit dipelajari untuk mengerjakan tugas. Dalam jarak dari satu sampai sepuluh, beberapa tugas adalah satu dan yang lainnya sembilan dalam memperhitungkan bagaimana mengerjakan tugas tersebut. Tambahan waktu dan usaha mungkin bisa dilakukan untuk mengatasi permasalahan dalam menyelesaikan tugas yang sulit dipelajari.

9. Merinci perlengkapan, alat-alat, dan barang-barang kebutuhan untuk melakukan tugas. Kesulitan dalam kinerja di beberapa tugas bisa saja berhubungan dengan angka dan kualitas alat-alat dan perlengkapan lain yang digunakan. Barang-barang perlengkapan yang rumit bisa menambah masalah daripada menjadi penyelesai masalah.

10. Catat dimana ketrampilan menjadi capaian terbaik.

"Analisis tugas sering dijadikan dasar untuk mengenali dan menyelesaikan masalah dalam dunia politik. Ketika analisis tugas telah dilakukan secara lengkap, mesti divalidasi atau dibandingkan dengan dengan kinerja di lokasi yang sebenarnya. Pengamatan dan wawancara dengan orang-orang yang bekerja adalah penting. Oleh karenanya peran komunikasi menjadi sangat penting dalam hal ini. Adalah sebuah komunikasi yang efektif akan berdampak pada berbagai progress dalam organisasi, dan komunikasi yang efektif itu mesti dilakukan dengan mendasarkan diri pada pengetahuan dalam berkomunikasi. Salah satu isu yang menjadi perhatian dalam kesadaran publik adalah kebutuhan untuk memastikan kesadaran publik menggunakan komunikasi berdasarkan pengetahuan"

(Cissna, 2009:4)

\section{E. Prosedur-prosedur Perbandingan}

Prosedur ini biasanya melibatkan perbandingan satu anggota organisasi dengan satu lainnya atau lebih global atau kriteria umum yang berupaya menilai efektivitas para anggota seluruhnya dalam organisasi. Pertanyaan yang perlu dijawab adalah, "Yang mana anggota yang paling sukses, kompeten, efektif, dan bernilai?” Dua tipe umum prosedur perbandingan 
menggunakan: rangking dan forced distribution.Rangking; Tiga tipe prosedur rangking adalah yang paling umum:

1. Rangking langsung, termasuk di dalamnya mengatur para karyawan yang dinilai sangat baik dalam kriteria digunakan, ditugaskan dengan kinerja paling baik di rangking pertama, selanjutnya adalah rangking kedua, dan seterusnya semua karyawan dievaluasi.

2. Rangking alternatif. Prosedur ini sedikit lebih rumit dan dimulai dengan daftar anggota organisasi secara alphabet yang akan dinilai. Orang yang menilai mewawancarai untuk mengenali anggota yang paling baik dan paling lemah dari daftar tersebut. Anggota organisasi terbaik di rangking nomor satu, dan yang paling lemah di rangking terakhir.

3. Perbandingan Berpasangan. Prosedur ini memiliki penilai dalam membandingkan setiap anggota.

Forced Distribution; sistem ini mensyaratkan para penilai untuk menetapkan persentasi para anggota yang dinilai dalam setiap kategori yang didasarkan pada beberapa faktor kinerja. Khususnya sebuah penetapan suatu pemaksaan penyaluran (forced distribution) ditetapkan 10 persen dari para karyawan untuk kategori superior, 20 persen untuk kategori excellent, 40 persen untuk kategori rata-rata, 20 persen untuk kategori di bawah rata-rata, dan 10 persen untuk kategori paling buruk (poorest).

\section{F. Standar Mutlak}

Sistem yang mengevaluasi karyawan menggunakan standar mutlak membandingkan individu-individu dengan model yang memiliki wibawa atau ukuran lebih baik dari karyawan lain. Standar adalah pernyataan yang menggambarkan apa yang diharapkan dari perilaku, nilai, kepantasannya, dan karakteristik lainnya. Ada dua cara mendasar menerapkan standar mutlak: kuantitatif dan kualitatif.

1. Metode kualitatif.

Kita mesti mengomentari tiga metode kuantitatif, semuanya mempertanyakan penilai untuk menentukan apakah standar tertentu diperlukan untuk karyawan yang khusus. Analisis kualitatif menransformasikan data ke dalam temuan. Tidak ada formula yang eksis untuk transformasi tersebut. Panduan, ya. Tetapi bukan resep. Arah penelitian dapat dan akan diajukan, tapi tujuan akhir tetaplah unik untuk setiap peneliti, yang mengetahui hanya ketika dan jika semua data sudah dikumpulkan. (Patton, 2002 : 432)

Dalam ilmu sosial pada umumnya dan dalam penelitian sosial khususnya, ada beberapa debat menyangkut apakah berguna menggunakan atau apakah valid untuk membedakan antara aplikasi dan penelitian teoritis. Konsekuensinya adalah disarankan 
semua penelitian mendasarkan pada asumsi teori tertentu, meskipun hanya secara implisit, tidak diakui atau buruk. ( Lewis, $2003: 25$ ). Analisis data kualitatif fokus pada:

- Reduksi data: merinci banyaknya data yang merepotkan ke dalam bagian pengelolaan dengan mengkoding, mencatat dan merumuskannya ke dalam bentuk dan konfigurasi sederhana.

- Interpretasi: membawa makna dan pandangan ke dalam kata-kata dan tindakan partisipan dalam penelitian dengan konsep general dan teori-teori (atau teori berlandaskan generalisasi) yang menjelaskan temuan-temuan. Anda kemudian mengomunikasikan makna dari yang ditemukan kepada orang lain melalui laporan tertulis ( Hollowey, $2002: 232$ ).

Pada umumnya pendekatan dalam penelitian komunitas menggunakan metodologi penelitian aksi partisipasi, berupaya memberikan suara kepada khalayak, untuk melihat kehidupan dan pengalaman mereka. Jika rumusan pentingnya kemudian memberdayakan mereka, komunitas mereka dan memromosikan perubahan sosial dan di level mikro kemudian dalam komunitas peneliti, dua pertanyaan muncul. Pertama, siapa yang membawa perubahan ini, dan ke arah mana seharusnya semua ini menuju? Kedua, jika kita berada di dalam bisnis yang memiliki kesadaran untuk maju, apakah kita melibatkan diri ke dalam proses( Roger, 2008 : 84) Secara umum penilai membuat sebuah penentuan-anggota melakukan apa yang diminta atau anggota tidak melakukan apa yang diminta.

Langkah-langkah yang diambil dimulai dengan mengumpulkan contoh-contoh kapan saatnya anggota dianggap sangat efektif atau sangat efektif-level tengah sering tidak termasuk - dari pengawas dan yang lainnya yang terbiasa dengan karyawan yang melakukan kerja sampingan, Efektivitas anggita sangat terkait dengan konsep diri seorang karyawan atas dirinya sendiri. Memikirkan tentang beberapa gambaran tentang diri Anda sendiri, Anda akan percaya bahwa Anda adalah seorang yang optimis atau seorang yan pesimis, ekstrovert atau introvert. Label-label diskripsi ini semestinya menggambarkan sesuatu tentang diri kita, dan faktanya, kita selalu menggunakan label-label ini sebagai cara mudah mendiskripsikan karakter kita ( Matsumoto, $1996: 35$ ). 
Faktor eksternal dan internal dalam diri manusia sering berbeda di antara satu sama lainnya, yang digambarkan sebagai berikut:

\begin{tabular}{|c|c|}
\hline $\begin{array}{l}\text { Information } \\
\text { Processing }\end{array}$ & $\begin{array}{l}\text { Internal make more attempts to acquire information, are less } \\
\text { satisfied with the amount of information they possess, and are } \\
\text { batter at utilzing information }\end{array}$ \\
\hline $\begin{array}{l}\text { Job } \\
\text { Satisfaction }\end{array}$ & $\begin{array}{l}\text { Internal are generally more satisfied, less alienated, less } \\
\text { roothless, and there is a stronger job satisfaction/performance } \\
\text { relationship for them }\end{array}$ \\
\hline Performance & $\begin{array}{l}\text { Internals perform better on learning and problem-solving } \\
\text { tasks, when performance leads to valued rewards. }\end{array}$ \\
\hline $\begin{array}{l}\text { Self-control, risk, and } \\
\text { anxiety }\end{array}$ & $\begin{array}{l}\text { Internals exhibit greater self-control, are more cautions, } \\
\text { engage in less risky behavior, and are less anxious. }\end{array}$ \\
\hline $\begin{array}{l}\text { Motivation, } \\
\text { Expectancies, and }\end{array}$ & $\begin{array}{l}\text { Internals display greater work motivation, see a stonger } \\
\text { relationship between what they do and what happens to them, } \\
\text { expect that worling hard leads to good performance, feel more }\end{array}$ \\
\hline Reponse to others & $\begin{array}{l}\text { Internals are more independent, more reliant on their own } \\
\text { judgment, and less susceptible to the influence of others; they } \\
\text { are more likely to accept information on its merit. }\end{array}$ \\
\hline
\end{tabular}

Contoh-contoh, ilustrasi-ilustrasi, atau peristiwa yang dianalisis untuk kesamaan dan pengelompokkan dengan kategori umum. The International Communication Association (ICA), sebuah proyek audit komunikasi organisasi, mengumpulkan ratusan critical incidents yang menggambarkan efektivitas tinggi dan ketidakefektivan tinggi komunikasi dalam organisasi. Delapan kategori umum isu penting dalam analisis insiden ini adalah: (1) Kejelasan peran, (2) Kecukupan informasi, (3) kesenjangan sintaksis, (4) Kecukupan umpan balik, (5) Penggunaan saluran, (6) Partisipasi dalam pengambilan keputusan, (7) Persepsi pada hubungan interpesonal, dan (8) Kompetensi komunikasi personal ( Richard, N, 2002 : 24)

\section{Metode Kuantitatif}

Penelitian sebagai sebuah proses tidak lain adalah suatu upaya mengumpulkan informasi tentang variabel dari ketertarikan dan mengubah nilai di dalam variabel sebagai sebuah fungsi dari lingkungan internal dan eksternal. Kuantitatif data adalah rekaman angkaangka yang merupakan hasil dari proses pengukuran yang bisa dihitung dalam proses matematika. Kuantitatif data kemudian dapat dikelompokkan ke dalam matrik dan non matrik data.( Singh, $2007: 122$ ) 
Penelitian kuantitatif terkait dengan angka dari pendekatan berbeda dari data yang dikumpulkan. Dalam sosiologi khususnya, survei sosial adalah satu metode utama dari pengumpulan data dengan mewujudkan fitur-fitur penelitian kuantitatif untuk dieksplorasi. Epistimologi di atas penelitian kuantitatif adalah mendirikan, yang meliputi prakondisi terhadap garansi pengetahuan, dan kehadiran angka-angka yang tak mungkin bisa cukup memuaskan (Bryman, $20014: 11$ ).

Dua tipe umum dari metode kuantitatif yang digunakan adalah: skala rating konvensional dan skala rating perilaku menginduk. Sayangnya skala rating konvensional membolehkan "efek halo" untuk berlangsung dengan kemungkinan memunculkan evaluasi yang bias terhadap karyawan. Cara seperti ini juga cenderung untuk fokus pada karakter personal daripada kinerja. Metode skala rating konvensional ini umumnya terdiri atas suatu serial elemen tentang karakteristik karyawan. Sebuah skala biasanya digunakan adalah skala lima poin. Dari lima sampai 25 karakteristik mungkin akan dievaluasi.

Sedangkan skala rating perilaku menginduk dikembangkan dengan menggunakan prosedur critical-incident. Para pengawas dan yang lainnya menggambarkan insiden di mana para karyawan menjadi sangat efektif atau sangat tidak efektif. Insiden-insiden dikelompokkan dengan kategori jumlah yang kecil yang memiliki kesamaan dalam perilaku. Penilai, pengawas dan yang lainnya emudian merata-ratakan setiap bagaimana kinerja yang sangat baik atau yang sangat tidak baik.

\section{G. Manajemen Berdasarkan Tujuan}

Untuk tambahan menggunakan prosedur perbandingan dan standar mutlak, tipe ketiga dalam metode penilaian nadalah manajemen dengan objektif (management by objectives/MBO). Sesuai namanya, manajemen ini berdasarkan pada asumsi bahwa tujuan dapat diraih lebih baik jika orang mengetahui apa yang harus diselesaikan dan progres menuju tujuan harus diukur dengan ukuran bahwa tujuan telah tercapai. Ini seperti premis berpikir sederhana, tetapi meminta perhatian kita untuk fakta bahwa memahami tujuan secara jelas adalah mudah untuk menyelesaikannya daripada mengaburkannya. Asumsi lain dari MBO adalah bahwa subordinat dan pengawas terlibat dalam mendifinisikan dan menjelaskan tujuan-tujuan yang mesti dicapai. Seperti halnya tujuan, ini juga adalah kemungkinan kuantitatif, dengan gambaran spesifik dan tanggal. Kekuatan dan kelemahan dari MBO terletak pada kemampuan untuk tujuannya yang unik dan standar untuk setiap karyawan. Individu berbeda dan kontribusi setiap individu akan menjadi pertimbangan. Dengan menyesal, pengenalan dan pemberian penghargaan dalam landasan yang layak menjadi lebih 
sulit untuk dicapai. Karena karyawan memainkan peran relatif langsung dalam mengenali, menyeting, dan mengevaluasi capaian tujuan.

\section{- Analisis Kebutuhan}

Suatu analisis kebutuhan terlihat dalam organisasi yang menjaga para karyawannya memberikan kontribusi besar mereka kepada organisasi. Prosedur untuk melaksanakan suatu analisis kebutuhan terutama terdiri dari berbicara dengan karyawan tentang pekerjaan mereka dan mendapatkan responds karyawan dan menulis pekerjaan mereka. Dua pendekatan mendasar juga menyediakan informasi tentang apa yang membuat karyawan melakukan yang terbaik: analisis data dan pengamatan klinis, wawancara dan penggunaan kuesioner.

Selanjutnya analisis data terdiri dari studi tentang:

a) Kebijakan organisasi, rencana-rencana, grafik organisasi, dan deskripsi posisi,

b) Keluhan anggota, penurunan, absensi, dan laporan kecelakaan,

c) Rekaman-rekaman pertemuan dan studi evaluasi program,

d) Penilaian kinerja di masa lalu dan survei perilaku, dan

e) Audit dan lapuran anggaran.

Pengamatan klinis merujuk pada membuat seperangkat pengamatan yang sangat objektif dan realistik, yang kontras dengan pengamatan subjektivitas tinggi dengan setting buatan. Objektivitas dicapai dengan pengamatan perilaku yang dapat dihitung dan diverifikasi. Tujuan pengamatan klinis adalah untuk mengenali dan merekam frekuensi dengan perilaku kritikal yang terjadi. Pengamatan klinis mewakili suatu sistem untuk mendiskriminasi antara kinerja sangat tinggi dan sangat rendah dari individual ataupun kelompok. Pengamatan klinis sangat sering digunakan ketika perbedaan antara kekhawatiran karyawan ataau kuantitas kinerja lebih baik dari kualitas kinerja. Ada tiga langkah umum untuk melakukan pengamatan klinis:

a) Tentukan perilaku yang akan diamati. Keputusan tentatif mengenai perilaku spesifik untuk diamati dapat dilakukan dengan wawancara, dan kemungkinan, pengalaman.

b) Pengamatan terhadap karyawan yang sangat tinggi efektivitasnya dan kepada beberapa karyawan yang sangat rendah efektivitasnya dan tetap menjaga pengamatan dicatat secara berbeda.

c) Melakukan pengamatan kepada setiap kelompok karyawan untuk periode yang ditentukan seperti 30 menit. 
- Attribution Theory

Dari apa yang diutarakan oleh R.Wayne Pace dalam buku Organizational Communication tersebut dalam menganalisis koumikasi sebuah organiasi di atas, selanjutnya dielaborasikan dengan apa yang diutarakan oleh Jhon R.Schermerhorn, Jr. dkk dalam buku Organizational Behavior. Bahwa untuk melakukan interpretasi terhadap efektivitas sebuah organisasi, digunakan teori atribusi (Attribution Theory)

Dengan memfokuskan pada bagaimana orang berupaya untuk (1) memahami penyebab terjadinya suatu peristiwa, (2) menilai tanggung jawab atas akibat suatu peristiwa, dan (3) mengevaluasi kualitas individu orang yang terlibat di dalam peristiwa"

Dalam aplikasinya, teori ini fokus pada apakah perilaku seorang disebabkan oleh faktor internal atau faktor eksternal. Faktor internal dipercaya berada di bawah kontrol individu. Misalnya kalau kalau Anda melihat kinerja si Polan jelek maka itu disebabkan karena ia memang malas. Sedangkan faktor esternal terlihat di luar dari diri individu. Jika Anda melihat kinerja di Polan jelek itu disebabkan karena perlengkapan yang dipakainya sudah tua. Berdasarkan teori atribusi ini, ada tiga faktor yang mempengaruhi faktor internal dan eksternal ini, yaitu: distinctiveness (perbedaan), consesus (kesepakatan), dan consistency (konsistensi).

Distinctiveness mempertimbangkan seberapa konsisten perilaku seseorang dalam situasi yang berbeda-beda. Jika kinerja si Polan rendah, terlepas dari kondisi peralatan kerjanya, kita cenderung memberikan memberikan penilaian kinerja jelek secara internal; jika kinerja jelek tidak biasa maka kita cenderung menentukan suatu penyebab eksternal untuk menjelaskannya.

Consensus menghitung bagaimana kemungkinan semua orang menghadapi situasi yang sama merespons secara serupa. Jika semua orang menggunakan perlengkapan seperti halnya si Polan yang memiliki kinerja buruk, kita cenderung mengelompokkan ke dalam faktor internal sebagai penyebab buruknya kinerjanya.

Consistency fokus pada apakah seorang individu merespons dengan cara yang sama sestiap waktu. Jika si Polan masuk dalam kelompok kinerja rendah, kita cenderung memberikan penilaian jelek dalam internal atribusi. Berbeda jika kinerja jelek si Polan adalah suatu insiden tersendiri, kita mengelompokkannya dalam faktor eksternal.

Sebagai tambahan dari tiga pengaruh tersebut, dua kesalahan memiliki dampak pada faktor internal dan eksternal. Keduanya yakni fundamental attribution error dan self-serving bias. Ketika seorang pengawas bertanya untuk melakukan identifikasi akibat dari kinerja 
yang jelek anak buahnya, ia akan lebih sering memilih individu yang memiliki kekurangan internal kurang memiliki kemampuan dan kurang memiliki upaya daripada bertanya pada kekurangan faktor eksternal. Inilah yang menunjukkan fundamental attribution error suatu kecenderungan untuk menganggap remeh pengaruh dari faktor situasional dan melebihlebihkan pengaruh faktor individu dalam mengevaluasi perilaku orang lain. Ketika bertanya untuk mengidentifikasi penyebab dari kinerja jelek mereka, namun, pengawas sepakat adanya kurangnya dukungan dalam ekternal atau situasional. Ini mengindikasikan suatu self-serving bias kecenderungan untuk menyangkal tanggung jawab individu untuk masalah kinerja tetapi menerima tanggung jawab individu untuk kinerja yang sukses.

Kesimpulannya, ada kecenderungan melebih-lebihkan faktor internal personal orang lain dalam perilaku mereka, dan menganggap kecil faktor-faktor eksternal dalam perilaku orang lain. Sebaliknya, cenderung untuk mengalamatkan kesuksesan kepada faktor-faktor internal kita dan mengalamatkan kegagalan pada faktor-faktor eksternal. Implikasi manajerial dari teori ini dapat dilacak kembali dari fakta persepsi pengaruh respons. Contohnya, seorang manejer yang merasa anak buahnya tidak bekerja baik dan menganggap alasannya adalah kekurangan faktor internal, kemungkinan akan memotivasi anak buahnya untuk bekerja lebih baik; kemungkinan tersebut dari perubahan eksternal, faktor-faktor situasional mungkin menghapus kendala pekerjaan, namun melengkapi dukungan organisasi yang lebih baik mungkin diabaikan. Pandangan seperti ini dapat mengorbankan keuntungan kinerja utama. Ini menarik karena self-serving bias, ketika mereka mengevaluasi perilaku mereka, para pengawas dalam studi awal mengindikasikan kinerja mereka dapat memberikan keuntungan organisasi dengan mendapatkan dukungan. Kemudian para pengawas yang dengan kemampuan atau keinginan sendiri bekerja keras tidak merasa menjadi masalah.

\section{H. Penutup}

Analisis terhadap kinerja anggota di dalam organisasi partai politik melibatkan sumber daya manusia di dalam organisasi tersebut. Selebihnya ada pengelompokkan di dalam ketrampilan yang masing-masing dimiliki oleh para karyawan, yang bagian terdasarnya ada pada konsep diri masing-masing karyawan terhadap dirinya sendiri. Efisiensi ataupun ketidakefisiensi kinerja karyawan pada dasarnya dapat dianalisis melalui beberapa bagian seperti berdasarkan prosedur perbandingan, analisis berdasarkan tujuan, dan analisis kebutuhan yang menyandarkan diri pada standar mutlak. Dan ajaran Islam sebenarnya telah melingkupi semua itu secara keseluruhan. 


\section{DAFTAR PUSTAKA}

Anthonissen, Peter F, Crisis Commmunication, practical PR strategies for reputation management and company survival (London and Philadelphia, Kogan Page, 2008)

Bryman, Alan, Quantity And Quality In Social Research (London and New York, Routledge, 2004)

Cox, Pat; Geisen, Thomas; and Green, Roger, Qualitative Research and Social Change (New York, Palgrave MacMillan, 2008)

Daymon, Christine, and Holloway, Immy, Qualitative Research Methods in Public Relations and Marketing Communications (London and New York, Routledge, 2002)

Frey, Lewrence R, Cissna, Kenneth N, Routledge Handbook of Applied Communication Research (New York and London, Routledge, 2009)

Harahap, Syahrin, Islam dan Modernitas, Dari Teori Modernisasi Hingga Penegakkan Kesalehan Modern, (Jakarta: Prenadamedia, 2O15)

Mark-Herbert, Cecilia and Rorarius, Jonas, Tools for Corporate Assessment of sustainable Development dalam Hallin, Anette and Gustavsson, Tina Karrbom, Organizational Cummnication and Sustainable Development: ITCs for Mobility (Hershey, New York, Information Science Reference, 2010)

Matsumoto, David, Culture and Psychology (Amerika Serikat, Cole Publishing Company, 1996)

Muhtadi, Burhanuddin, Dilema PKS, Suara dan Syariah (Jakarta: Gramedia, 2012)

Pace, R.Wayne, Organizational Communication; Foundations for Human Resource Development. Part Three: Human Resource Development Roles And Organizational Communication, (New Jersey: Prentice-Hall, Inc., 1983)

Patton, Michael Quinn, Qualitative Research \& Evaluation Methods (London and New Delhi, Sage Publications, 2002)

Ritchie, Jane and Lewis, Jane, Qualitative Research Practice (London, Sage Publications, 2003)

Romli, Khomsahrial, Komunikasi Organisasi Lengkap (Jakarta: Grasindo, 2O11)

Russell, Nicholas, Communicating Science, Professional, Popular, Literary (London, Cambridge, 2010)

Sahputra, Dedi, Komunikasi Politik Partai Politik Islam (Yogyakarta, Orbit, 2016)

Singh, Kultar, Quantitative Social Research Methods (Los Angeles, Sage Publications, 2007)

Schermenrhorn, Jhon R.Jr; Hunt, James G; and Osborn, Richard N., Organizational Behavior 
7 th Edition (Phoenix, AS, Wiley, 2002)

Warjio, Dilema Politik Pembangunan PKS, Islam dan Konvensional (Medan: Perdana Publishing, 2016)

, Gagalnya Partai Politik Islam (Yogyakarta: Pustaka Pelajar, 2018)

, Politik Pembangunan, Paradoks, Teori, Aktor, dan Idologi (Jakarta: Kencana, 2016) 